Bangladesh J. Bot. 49(4): 1095-1101, 2020 (December)

\title{
ADVERSE EFFECTS OF NITROGENOUS COMPOUNDS ON NITROGEN - FIXING CYANOBACTERIUM ANABAENA SOLITARIA KLEBAHN
}

\author{
Nermin Adel El Semary*1 \\ Department of Biological Sciences, College of Science, \\ King Faisal University, Al-Ahsa, PO: 400, Post code: 31982, Kingdom of Saudi Arabia
}

Keywords: Anabaena solitaria, Biofertilisers, Heterocysts, Heterotrophic bacteria, Nitrogenous compounds

\begin{abstract}
The nitrogen-fixing heterocystous cyanobacterium Anabaena solitaria was tested for its response to different concentrations of nitrogen sources, namely nitrate and ammonia. To compare both the effect of concentration and type of nitrogen source, gradual concentrations were prepared for both ammonia and nitrate. The results showed concentration was significantly important on the frequency of heterocyst formation where highest nitrogen compounds concentrations were inhibitory for heterocyst formation. On the other hand, the effect of the type of nitrogenous compounds tested was insignificant which only proves that they are equally usable by cyanobacteria which will use them instead of transforming one of its cells to heterocyst thus not performing nitrogen fixation. Results also revealed the massive growth of heterotrophic bacteria in presence of nitrogenous compounds. This indicates that the presence of nitrogenous compounds in fields in which nitrogen-fixing cyanobacteria are to be used as biofertilizers can be inhibitory for nitrogen fixation and stimulatory for heterotrophic bacterial growth which could be pathogenic and harmful to plants. The use of more nitrogen-fixing cyanobacteria with the minimum amount of nitrogenous compounds is recommended.
\end{abstract}

\section{Introduction}

Cyanobacteria (Blue green algae) are oxygenic phototrophs which obtain their energy through photosynthesis. They have unique physiological properties and universal ubiquity. Cyanobacteria exist in diverse habitats even in extreme conditions such as hot springs, deserts and saline basins (Seckbach 2007). The functional roles played by cyanobacteria are the performance of photosynthesis and nitrogen fixation in addition to the production of organic compounds (Hashem et al. 1996, Komárek 2006). Soil factors such as $\mathrm{pH}$, chemical nature, granulometric and saline structures affect cyanobacteria (Temraleeva et al. 2016). Cyanobacteria like Nostoc, Anabaena, Oscillatoria, Aulosira, Lyngbya etc. have an important role in biofertlization because they perform atmospheric nitrogen fixation (Begum et al. 1996, Begum and Mandal 1997). It is believed that cyanobacteria enhance the yield of agricultural crops by 10 - 15\% (Youssef and Eissa 2014). Several cyanobacterial strains produce heterocyst which contain active nitrogenase enzyme that plays a vital role in nitrogen fixation under unfavorable environmental conditions. This enzyme catalyses the conversion of atmospheric nitrogen to ammonia, nitrites and nitrates which can be absorbed by plants to build protein and nucleic acids. Cyanobacteria have the potential to reclaim high saline soil and their application in fields is suggested to reduce the usage of chemical fertilizer, urea (Begum et al. 2013). They can enhance the organic matter and also, they can prevent the soil erosion. Cyanobacteria have an important role in rice filed because they produce growth-promoting substances and they increase phosphorus by producing organic acids that are exploited in the prevention of soil erosion process (Kumar et al. 2012). In the present study, it is

*Author for correspondence: <nelsemary@kfu.edu.sa>. ${ }^{1}$ Botany\& Microbiology Department, Faculty of Science, Helwan University, Cairo, Egypt post code: 11795 
hypothesized that the cyanobacterial nitrogen-fixing capabilities might be affected by the presence of commercial fertilizers in the soil. However, nothing is known about the concentration of nitrogenous compound that can be inhibitory for nitrogen fixation. So far nothing is known about which nitrogenous fertilizer would be more inhibitory for heterocyst formation and stimulatory for bacterial growth. Therefore, we endeavored to investigate this using both epi-fluorescent and electron microscopy.

\section{Materials and Methods}

Anabaena solitaria monoculture was exposed to equimolar concentrations of nitrate and ammonia (from $0.5,1.0,1.5,2.0$ and $2.5 \mu \mathrm{M}$ ) in addition to the control in which no nitrogenous compound was added to observe the effect of different concentrations of nitrate and ammonia.

Epi-fluorescent microscopy (El Semary 2005) with UV filters was used alongside scanning electron microscopy to detect bacteria stained with DAPI dye. For this purpose, samples of Anabaena filaments were filtered using a filtration unit where syringe filters units $(25 \mathrm{~mm}$ diameter) and $25 \mathrm{~mm}$ diameter polycarbonate filters of $0.2 \mu \mathrm{m}$ pore size (Milipore, Ireland) were used. Samples were injected onto the filter unit using a syringe. The filter was immersed in solution of $4 \%$ formaldehyde/PBS buffer (phosphate buffered saline; $130 \mathrm{mM} \mathrm{NaCl}, 10 \mathrm{mM}$ sodium phosphate buffer, $\mathrm{pH} 7.2$ ) for a period of $30-45 \mathrm{~min}$. Eighty to $200 \mu \mathrm{l}$ of $50 \mu \mathrm{g} / \mathrm{ml}$ lysozyme in distilled sterilized water were added to the filter followed by $40-100 \mu 1$ of sucrose solution $\left(200 \mu \mathrm{g} / \mathrm{ml}\right.$ in distilled water). The slide was then incubated at $37^{\circ} \mathrm{C}$ for $15-20 \mathrm{~min}$ after which the sample was treated with $45-80 \mu$ l of proteinase $\mathrm{K}(20 \mu \mathrm{g} / \mathrm{ml} \mathrm{TE}$ buffer; $\mathrm{pH} 7.4,10 \mathrm{mM}$ Tris $\mathrm{HCl}(\mathrm{pH} \mathrm{7.4),} 1 \mathrm{mM}$ EDTA ( $\mathrm{pH} \mathrm{8.0)})$ for $10-15 \mathrm{~min}$ at $55^{\circ} \mathrm{C}$. The samples fixed on the millipore filter were then placed again in $4 \%$ formaldehyde solution $(\mathrm{v} / \mathrm{v})$ for $30 \mathrm{~min}$. Then incubated for two hrs in dim hybridization chamber at $49^{\circ} \mathrm{C}$ with the hybridization buffer that contained $5 \times$ SET, $0.1 \%(\mathrm{v} / \mathrm{v})$ Nonidet-P40, $30 \mu \mathrm{g} / \mathrm{ml}$ Poly A. A super stock of $25 \times$ SET buffer included $3.75 \mathrm{M} \mathrm{NaCl}, 25 \mathrm{mM}$ EDTA, and $0.5 \mathrm{M}$ Tris $\mathrm{HCl}(\mathrm{pH}$ 7.8). The filter was briefly washed in $1 \times$ SET buffer prewarmed to the hybridization temperature and then placed on a clean slide. The $100 \mu$ of prewarmed $1 \times$ SET was applied to the filter at the hybridization temperature for 15 - 25 min. Finally, 20 - $30 \mu 1$ of vectashield (Vector laboratories, Inc Burlingame, CA 4990)/DAPI (Sigma-Aldrich, UK) mixture was applied directly onto the filter in the proportion 2: $1(\mathrm{v} / \mathrm{v})$ in distilled water containing DAPI at a final concentration of $1 \mu \mathrm{g} / \mathrm{ml}$ : NB. Vectashield acts as an antifading reagent whereas DAPI acts as DNA stain. Slides were then observed using epifluorescence Leitz Orthoplan microscope (Wetzlar, Germany), equipped with UV lamp and appropriate filter. Microscopic examination was performed using the oil immersion lens 100x PHACO. A digital camera (cool pix 990 digital camera; $3.34 \times 106$ pixels; Nikon, Japan) was used to collect image using the DAPI filter: images were saved as jpg files.

For electron microscopy, the cyanobacterial biomass was placed in Eppendorf tubes filled with fixative consisting of $2.5 \%$ glutaraldehyde in sodium cacodylate buffer $0.1 \mathrm{M} \mathrm{pH} 7.2$ for four hrs at room temperature, then washed three times in $0.1 \mathrm{M}$ cacodylate buffer. The wash buffer was then replaced with a fixative consisting of $1 \%$ osmium tetraoxide in sodium cacodylate buffer 0.1 $\mathrm{M} \mathrm{pH} 7.2$ for one hr at room temperature. The material was then dehydrated by passing it through ethanol ascending series 30,50, 70, 90 and 100\% twice for ten min at each step. The biomass was transferred into microporous specimen capsules (supplied by Agar Scientific, USA) filled with ethanol, these capsules were then placed in the critical-point drier (Samdri 780) (Tousimis Research Corp. Rockville Maryland USA) and critical point dried using liquid carbon dioxide. In order to document the response towards each treatment scanning electron miroscopy was used. The dried material was then mounted on SEM specimen holders by means of carbon adhesive 
discs (supplied by Agar Scientific, USA) and then sputter coated with gold in a Polaron sputter coater. Sections were examined using a JEOL $1200 \mathrm{WX}$ electron microscope. Images were recorded on Kodak Electron Microscope Film 4489, (USA Minitab package version 13 (USA) were used for statistical analysis (El Semary 2005).

\section{Results and Discussion}

The frequency of heterocysts was indicated by the number of vegetative cells delimited by heterocysts. As the concentration of nitrogenous compounds increased the number of vegetative cells delimited by two heterocysts increased reaching the highest level when using the highest concentration of both nitrate and ammonia (Table 1). DAPI is a fluorescent DNA dye and when cyanobacterial cells and associated bacteria are treated with DAPI they fluoresce under UV, thereby exposing the presence of bacteria and its exact location around the cyanobacterial filament. The bacterial association around the filaments and around the heterocyst particularly decreased significantly, if not, completely as judged by the increase of number of undifferentiated vegetative cells, the shift in bacterial distribution to the external solution rather than the filament and the massive bacterial proliferation (Figs 1- 3 using epi-fluorescent microscope under UV and Figs 4-10 using scanning electron microscope).

Table 1. The number of vegetative cells delimited by two heterocysts in filaments.

\begin{tabular}{|c|c|c|c|c|c|}
\hline $\begin{array}{l}{ }^{1} \text { Nitrogenous } \\
\text { compounds }\end{array}$ & $\begin{array}{c}\text { Conc. } \\
\mu \mathrm{M}\end{array}$ & $\begin{array}{c}\text { Filament } \\
1\end{array}$ & $\begin{array}{c}\text { Filament } \\
2\end{array}$ & $\begin{array}{c}\text { Filament } \\
3\end{array}$ & $\begin{array}{c}\text { Filament } \\
4\end{array}$ \\
\hline Ammonium & 0.0 & 8 & 10 & 8 & 10 \\
\hline Nitrate & 0.0 & 10 & 12 & 10 & 11 \\
\hline Ammonium & 0.5 & 14 & 14 & 13 & 12 \\
\hline Nitrate & 0.5 & 13 & 12 & 15 & 12 \\
\hline Ammonium & 1.0 & 16 & 14 & 17 & 17 \\
\hline Nitrate & 1.0 & 15 & 15 & 16 & 15 \\
\hline Ammonium & 1.5 & 17 & 19 & 15 & 18 \\
\hline Nitrate & 1.5 & 16 & 17 & 16 & 17 \\
\hline Ammonium & 2.0 & 16 & 14 & 15 & 16 \\
\hline Nitrate & 2.0 & 18 & 21 & 20 & 20 \\
\hline Ammonium & 2.5 & 18 & 18 & 20 & 18 \\
\hline Nitrate & 2.5 & 20 & 20 & 20 & 20 \\
\hline
\end{tabular}

\footnotetext{
${ }^{1}$ Analyses of covariance was performed in Minitab package. The analysis retrieved two $p$ values, the first indicating highly significant effect of concentrations on the number of vegetative cells whereas the second indicated insignificant effect of type of nitrogenous compound.
}

The association between heterotrophic bacteria and cyanobacteria has been reported to affect the primary production and nutrient recycling (Secker et al. 2016). Bacterial assemblages find hospitable microenvironment around the heterocyst of cyanobacteria as it leaks many beneficial nutrients to those heterotrophic bacteria (Paerl and Gallucci 1985). The external environment is also known to affect this microbiota (Paerl 2017). 
The change in the bacterial distribution from filament to external solution was also observed by Paerl and Gallucci (1985) on different nitrogenous compounds. They reported that the addition of three soluble nitrogenous compounds serine, glycine and peptone over a range of concentrations to nitrogen-fixing cultures of Anabaena oscillarioides led to a significant reduction in the number of bacteria epiphytic on heterocysts, the negative effect being concentration-dependent. They also reported that on removal of these substances (chemoattractants) by filtration and rinsing of cyanobacteria and associated bacteria, heterocyst-specific attachment resumed which was attributed to the presence of chemotactic agents leaking from heterocyst. Amino acids could be the probable chemotactic agents, since they are known to be excreted by nitrogen-fixing Anabaena sp. and elicit very strong chemotactic responses in pseudomonads. They also reported that there are other non-nitrogenous attractants released from heterocysts, vegetative cells and akinetes. It is a paradox for cyanobacteria to perform nitrogen-fixation in the presence of external nitrogenous compounds as Paerl (2017) indicated and the concentration of these nitrogenous compounds and their nature play a role in inducing or inhibiting nitrogen-fixation. With regard to the inhibition of
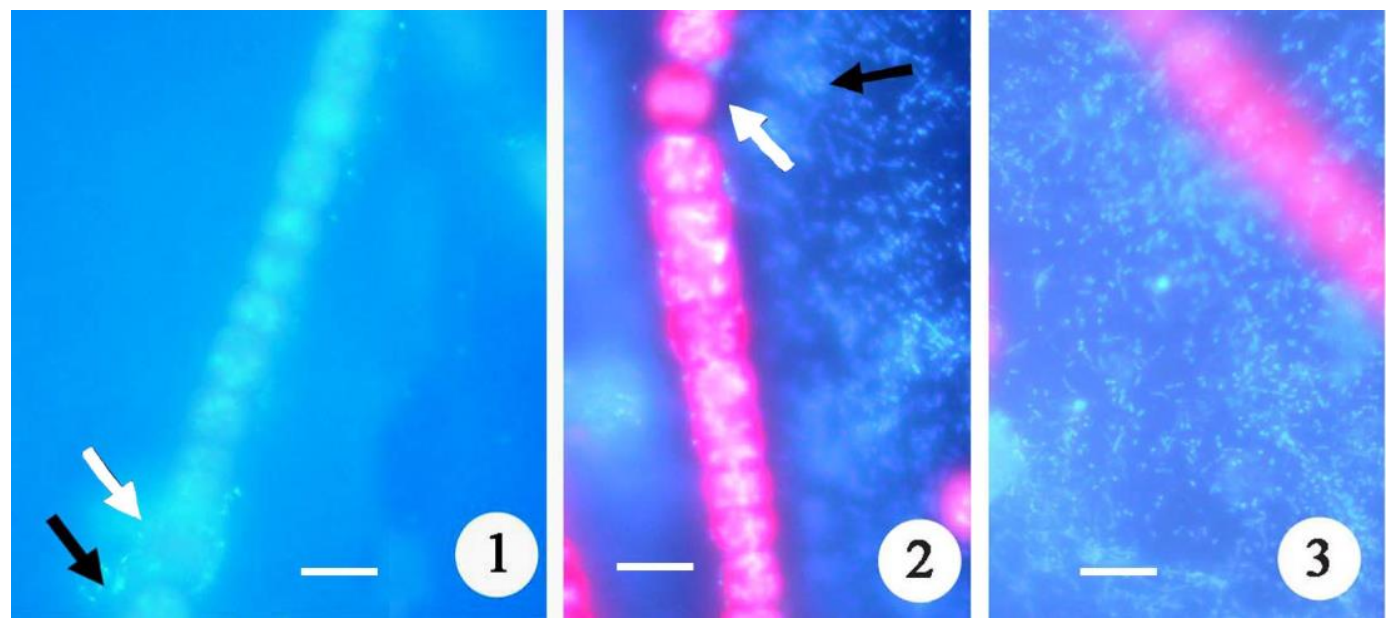

Figs 1-3: 1. UV-illuminated epifluorescent micrograph showing the association of heterotrophic bacteria (fluorescent DAPI that stains DNA under UV) around heterocyst (denoted by white arrow) using zero concentration of nitrogenous compounds. The bacteria (fluorescent dots denoted by black arrow) are mainly concentrated around heterocyst as well as along the filament. Bar $=20 \mu \mathrm{M}$. 2. Epi-fluorescent micrograph using UV filter where the blue fluorescent dots indicate heterotrophic bacteria (denoted by black arrow) at concentration $2 \mu \mathrm{M}$ of nitrate. Bar $=20 \mu \mathrm{M}$. The distribution of bacteria is more general in the filament vicinity not specifically focused on the heterocyst (denoted by white arrow). 3. Epi-fluorescent micrograph with the of addition of nitrate at $2.5 \mu \mathrm{M}$ concentration. Bar $=20 \mu \mathrm{M}$. The distribution of bacteria is more general in the vicitniy with inhibition of frequent heterocyst formation.

heterocyst formation in response to addition of nitrogenous compounds, Carr and Whitton (1982) reported that the addition of ammonium suppressed the formation of intercalary heterocysts in Nostochopsis lobatus whereas heterocyst formation by Anabaena CA is much more strongly inhibited by nitrate than ammonium which is reversible inhibition that can be reversed by methionine sulphoximine. This would suggest that the inhibition is mediated by intracellular ammonium. However, it was found that both ammonia and nitrate addition caused gradual inhibition to the heterocyst formation. However, at the high concentrations it was noticed that there was a general increase in Anabaena growth with the nitrate treatment unlike the ammonium treatment, which was lethal to the cyanobacterial filament (caused breakage of filaments). Nevertheless, it was hypothesised that different nitrogen sources would lead to a difference in 
heterocyst frequency in the filaments. To test this, gradient concentrations were prepared for ammonium and nitrate salts. Nonetheless, both treatments showed a strong response exhibited by the increase in the number of vegetative cells between two heterocysts in presence of salt as compared to those in salt absence. Analysis of covariance was carried out using MINITAB software statistical package in which the response was the number of vegetative cells and the
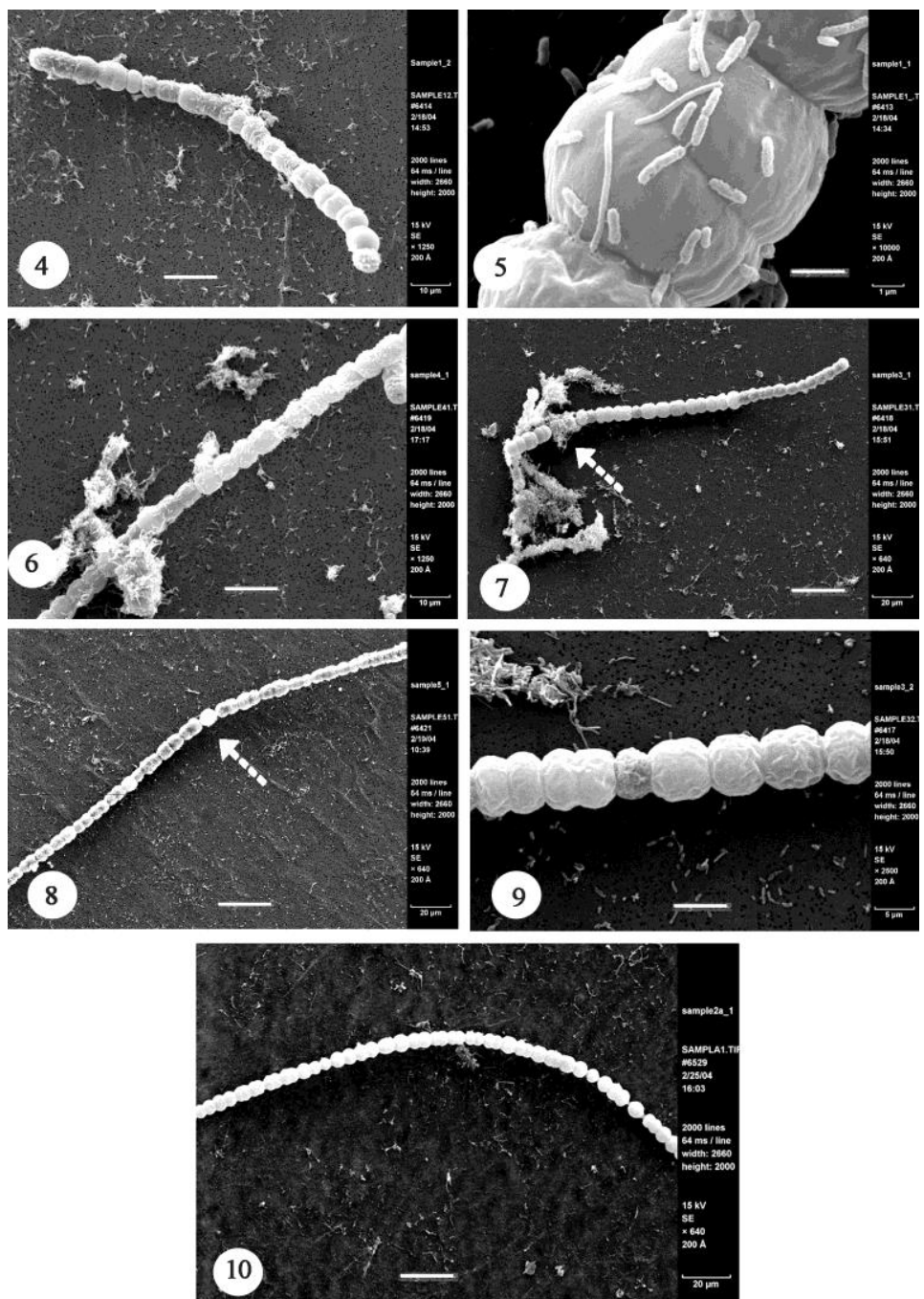

Figs 4-10. 4. Scanning electro-micrograph showing the zero $\mu \mathrm{M}$ concentration of nitrate. Bar $=1 \mu \mathrm{M}$. 5. Scanning electromicrograph showing the zero $\mu \mathrm{M}$ concentration of ammonia. Bar $=1 \mu \mathrm{m}$. 6. Scanning electro-micrograph showing accumulation of bacteria around heterocyst (denoted by white arrow) at $0.2 \mu \mathrm{M}$ nitrate but the distribution is beginning to shift to solution. Bar $=5 \mu \mathrm{m}$. 7. Scanning electro-micrograph of the cyanobacterial filament of A. solitaria at $1.5 \mu \mathrm{M}$ concentration of ammonia. There is a breakage in the filament. White arrow denotes the heterocyst. Bar $=20 \mu \mathrm{m} .8$. Scanning electro-micrograph of the cyanobacterial filament of $A$. solitaria the $1.5 \mu \mathrm{M}$ concentration of nitrate. The white arrow denotes the heterocyst. Bar $=20 \mu \mathrm{m}$. 9. The $2 \mu \mathrm{M}$ of concentration. The heterocyst and cells of $A$. solitaria have no apparent bacterial infection but bacteria are found in the surroundings. Bar $=5 \mu \mathrm{M}$. 10. Scanning electro-micrograph of cyanobacterial filament of $A$. solitaria at $2.5 \mu \mathrm{M}$ nitrate. Bar $=20 \mu \mathrm{m}$. 
model was the two salt treatments and the covariant was the concentration. By using this test, it was possible to factor out the response of the organism to change in salt gradient per se and then test to see if there was a differential response to the type of nitrogen source alone. The analysis retrieved two $\mathrm{p}$ values the first of which was 0.000 , which means highly significant effect on the number of vegetative cells between two heterocysts due to an increase in concentration of both nitrate and ammonium. The second $\mathrm{p}$ value was 0.738 which means that there was no significant difference in the response of the organism grown on the ammonium salt or the nitrate salt. Therefore, the original hypothesis was rejected. Therefore, the original hypothesis that there is a differential response towards ammonia and nitrate is rejected. Both cause heterocyst inhibition in a concentration-dependent manner.

Overall, the use of nitrogen-fixing cyanobacteria as a biofertilizer with other nitrogenous compounds would lead to inhibition of frequent heterocyst formation thus inhibiting nitrogen fixation and possibly inhibiting other growth promoting substances leaking from heterocyst. So, if chemical fertilizers are used in combination with cyanobacteria, they should be diluted to allow heterocyst formation.

\section{Acknowledgement}

The author acknowledges the Deanship of Scientific Research at King Faisal University for the financial support under Nasher Track (Grant No206049).

\section{References}

Carr NG and Whitton BA 1982. The Biology of Blue-Green Algae. Botanical Monograph. Vol. 9. University of Californic Press, Berkely and Los Angelos.

Begum ZNT and Mandal R 1997. Nirogen fixing capacity of some cyanobacterial strains from Bangladesh. Phytol. Res. 10(1-2): 67-73

Begum ZNT, Mandal R, Khan Zahed UM and Hossain MZ 1996. Prospect and potentiality of cyanobacteria as an alternative source of nitrogen fertilizer in Bangladesh rice cultivation. In: Biological Nitrogen Fixation Associated with Rice Production. M. Rahman (ed.) pp. 119-131. Kluwer Academic Publishers, Great Britain.

Begum ZN Tahmida, Manal R and Amin FB. 2013. Growth of cyanobacteria in saline soil, amended with NP fertiliers. J. Asiat. Soc. Bangladesh (Sci.). 39(2): 167-171.

El Semary NA 2005. Anabaena and associated bacteria: Molecular approaches to studying microbial community structure and taxonomy. Ph.D. thesis, University of Bristol, UK.

Hashem MA, Islam MR, Jahiruddin M and Asaduzzaman M 1996. Enrichment of indigenous blue-green algae population in rice fields and evaluation of its effect on rice cultivation. In: Biological nitrogen fixation associated with rice production. Rahman M, Poddar AK, Hove C, Begum ZN Tahmida, Heulin $\mathrm{T}$ an Hardnann A (Eds), Kluwer Academic Publications, Great Britain, pp. 159-170.

Komárek J 2006. Cyanobacterial taxonomy: Current problems and prospects for the integration of traditional and molecular approaches. Algae-Inchon. 21.4 (2006): 349.

Kumar SR, Sathish KV and Bhaskara Rao 2012. Biological nitrogen fixation: A Review. Int. J. Adv. Life Sci. 1(2012): 1-6.

Paerl, Hans. (2017). The cyanobacterial nitrogen fixation paradox in natural waters. F1000 Faculty Review. 6. 244. 10.12688/f1000research.10603.1.

Paerl HW and Gallucci KK 1985, Role of chemotaxis in establishing a specific nitrogen-fixing cyanobacterial-bacterial association. Science 8: 227(4687): 647-649

Secker N, Griffith J, Laurie R, McNoe L, Guy P, Orlovich D and Summerfield T 2016. Characterization of the cyanobacteria and associated bacterial community from an ephemeral wetland in New Zealand. J. Phycol. 52. 10.1111/jpy.12434. 
Seckbach J 2007. Algae and cyanobacteria in extreme environments. Vol. 11. Springer Science \& Business Media.

Temraleeva, A.D., Dronova, S.A., Moskalenko, S.V. 2016. Modern methods for isolation, purification, and cultivation of soil cyano-bacteria. Microbiology 85(4): 389-399.

Youssef MMA and Eissa MFM 2014. Biofertilizers and their role in management of plant parasitic nematodes. A review. E3 J. Biotechnol. Pharm. Res. 5(1):1-6.

(Manuscript received on 26 September, 2019; revised on 6 April, 2020) 